Omni-Akuatika, 14 (2) : 52-58,2018
ISSN: 1858-3873 print / 2476-9347 online
Research Article
journal homepage: http://ojs.omniaquatika.net

\title{
Heat Shock and Its Consequences on Early Life Performance of Stripped Catfis (Pangasianodon hypophthalmus)
}

\author{
Prama Hartami ${ }^{* 1}$; Odang Carman ${ }^{2}$; Muhammad Zairin $\mathrm{Jr}^{2}$; Alimuddin ${ }^{2}$ \\ *) Postgraduate Student of Bogor Agricultural University, \\ IPB Darmaga Campus, Bogor 16680, Indonesia \\ $\left.{ }^{1}\right)$ Lecturer of Aquaculture Study Program, Malikussaleh University \\ Jl. Cot Tgk. Nie Reuleut Muara Batu, North Aceh 24355, Indonesia \\ $\left.{ }^{2}\right)$ Lecturer of Aquaculture Study Program, Bogor Agricultural University \\ IPB Darmaga Campus, Bogor 16680, Indonesia
}

"Corresponding author: odangcarman@gmail.com

\begin{abstract}
Researchers have widely applied heat shock on zygote stadia of domesticated aquatic animals especially for the purpose of ploidy manipulation in fish to accelerate growth, intermediate products for the production of infertile seeds, providing prospective brood stock as well as the monosex population. This is certainly an interesting study to see how far the impact of heat shock on the early development stages. This experiment used a $42{ }^{\circ} \mathrm{C}$ heat shock for 2.5 minutes on the zygote at different initial time i.e. $28.5 ; 29 ; 29.5 ; 30$ and 30.5 minutes after fertilization. All treated larvae and control were reared in a 25 liters plastic container at density of 5 larvae per liter. The results showed that high percentage of fertilization rate were $92.61 \%$ to $96.32 \%$ and hatching rate was $85.33 \%$ without any abnormalities were achieved in the control. While in all treatments had a very low hatching rate of $4.12 \%$ to $8.93 \%$ with relatively high abnormalities of $12.36 \%$ to $27.60 \%$ and a significant differences $(P<0.05)$ compared to controls, but survival rate, specific growth rate and feed conversion ratio after 30 days rearing period showed no significant difference $(P>0,05)$. In terms of seed production, the heat shock treatment will limit $78 \%$ to $82 \%$ of larvae production.
\end{abstract}

Keywords: Deformed, hatchlings, experiments, death, striped catfish

\section{Introduction}

Striped catfish is one of the most developed aquaculture commodities in Indonesia especially in Java and Sumatera with relatively high production level of 437,111 tons in 2016, and 2018 is targeted to reach 604,587 tons (KKP 2017). Thus making it as cultivated organism that has prospectively to be developed on a large scale. It is also one of the commodities used as raw material of the fillet industry with optimum size when harvest is 1.25 $\mathrm{kg} /$ individual (Islami et al., 2014; Akter et al., 2014). This implies the length of time of cultivation and many feeds consumption, So it is necessary to improve the performance of growth and feed efficiency towards better, like improving genetic quality through heat shock technique.

The application of physical shock (temperature and pressure) as well as chemical in the manipulation of chromosome set were usually performed on the zygote stadia both at the time of meiosis II (shortly after fertilization) and before the first mitotic (first cleavage). The superiority of manipulation technique of chromosomes set in fish is to increase growth, feed efficiency, environmental resistance, and infertile fish production (Thorgaard 1983), have better texture and meat quality (Lefevre et al., 2015) and more appealing form (Kadi 2007). Another advantage of polyploid fish is that it generally does not cause a decrease in genome diversification as in plants (Zhan et al., 2014). Individual polyploids especially triploid and tetraploid are particularly adaptable and can be used as environmental control (control of growth) for other individuals (Kadi 2007).

Research on polyploid fish production has been done by researchers in various species with variations in yield. In general, the researchers have performed ploidy analysis and separated the organism (polyploid and diploid) to compare their growth rate. On the 
other hand, post-shock studies of larvae that are successfully hatched and have not been analyzed the level of their ploidies are not widely practiced. So that authors need to know how the impact of the heat shock on the growth performance of zygote striped catfish that successfully hatched before known the ploidy level of the larvae. However, this study is limited only to a heat shock trial on a zygote prior to the first mitotic.

\section{Materials and Methods}

\section{Design of Experiments}

The heat shock treatments were performed based on the best results of previous researchers in inducing triploid (Ibrahim et al., 2016) and tetraploid (Buulolo et al., 2017) of striped catfish. The experiment was designed by applying six treatments plus a control with three replications as follows:

$\mathrm{P} 1$ : $42^{\circ} \mathrm{C}$ shock for $2.5^{\prime}, 2^{\prime}$ ' after fertilization P2 : $42^{\circ} \mathrm{C}$ shock for $2.5^{\prime}, 28.5^{\prime}$ after fertilization P3 : $42^{\circ} \mathrm{C}$ shock for $2.5^{\prime}, 29^{\prime}$ after fertilization P4 : $42^{\circ} \mathrm{C}$ shock for $2.5^{\prime}, 29.5^{\prime}$ after fertilization P5 : $42^{\circ} \mathrm{C}$ shock for $2.5^{\prime}, 30^{\prime}$ after fertilization P6 : $42^{\circ} \mathrm{C}$ shock for $2.5^{\prime}, 30.5^{\prime}$ after fertilization P7 : Control (without heat shock)

\section{Heat shock treatment}

Fertilization was conducted at $29{ }^{\circ} \mathrm{C}$ by mixing semen and ovulated eggs. Prior to first cleavage i.e. $28 ; 28.5 ; 29 ; 29,5 ; 30 ; 30,5$ min after fertilization, the zygotes were shocked at $42{ }^{\circ} \mathrm{C}$ for $2.5 \mathrm{~min}$ by transferring into prepared water bath. After heat shocking 6800 treated eggs were incubated in aquaria at normal temperature of $28-30{ }^{\circ} \mathrm{C}$ until hatched $(20-24$ hours after fertilization).

\section{Larvae rearing management}

The larvae of treatments and control groups were reared in a $200 \times 100 \times 40 \mathrm{~cm}^{3}$ fiber tank equipped with aeration system for seven days. The larvae were fed on Artemia naupli during first three days and mixed with tubificid worm during the rest four days.

\section{Nursery management}

Nursery management was conducted for 30 days using a 25 liters plastic container at density of 5 larvae per liter. The fish were fed on $26 \%$ protein content commercial feed three times a day at $8 \%$ feeding rate of total biomass. Sampling simultaneously for body weight and body length measurements every 10 days. During the nursing period, $70 \%$ water exchange was conducted at the same time of sampling. In addition waste and feces were removed daily by syphoning the media culture to maintain an optimum condition. At the same time, dead fish were checked and collected for survival rate and feed efficiency analysis.

\section{Data analysis}

Collected data especially hatching rate, survival rate and abnormality were determined according to Effendie (2002); specific growth rate and feed conversion ratio were calculated referring to De Silva and Anderson (1995). Those data were than analyzed statistically by applying F-Test (Anova) with the best response at $95 \%$ confidence range and the Tukey Multiple Range Test to compare the values between treatments. The software used was Minitab $16^{\text {th }}$ and Ms. Excel 2013.

\section{Results and Discussion}

\section{Fertilization, hatching and survival rate}

Observation on the zygotes at 7 hours after fertilization indicated that the ovulated eggs and sperm that used in the experiment have a good qualities, this can be interpreted from the high fertilization of $94.61 \%$. The percentage value was obtained from three replicates of observations using 218 samples as shown in Table I.

Table 1. Fertilization rate of stripped catfish ( $P$. hypophthalmus) observed at 7 hours after fertilization

\begin{tabular}{cccc}
\hline Replicate & $\begin{array}{c}\text { Number of sample } \\
(\text { egg) }\end{array}$ & $\begin{array}{c}\text { Unfertilized egg } \\
(\text { egg) }\end{array}$ & $\begin{array}{c}\text { Fertilization rate } \\
(\%)\end{array}$ \\
\hline 1 & 207 & 12 & 94.52 \\
2 & 235 & 8 & 96.71 \\
3 & 213 & 17 & 92.61 \\
\hline Average & $\mathbf{2 1 8 . 3 3}$ & $\mathbf{1 2 . 3 3}$ & $\mathbf{9 4 . 6 1}$ \\
\hline
\end{tabular}


Based on Table 2, the highest hatching rate of $86.09 \%$ was obtained in control. While, very low hatching rate values with a range of $3.20-7.50 \%$ were obtained in all treatment groups. The very low hatching rate in these groups were strongly influenced by physical shocks as also reported by other researchers (Ding et al., (2007; Lebeda and Flajshans, 2015), resulting lethal embrios prior to hatching (Lagler et al., 1977). Furthermore, this phenomenon explains that the effects of physical and chemical Furthermore this phenomenon explains that the effects of physical and chemical shocks cause damage to the cytoplasm (Tave, 1993), as well as damage to the spindle fibers during cell division (Gill et al., 2016). Hersberger and Hostuttler (2005) mentioned that there were various result of physically induced zygote that can survive to hatch with low hatching rate of $8-40 \%$. Moreover, Fetherman et al. (2016) state that hatching success depends on several factors including innitial time, duration, and temperature of shock, gamets quality, and egg incubation conditions. The results of statistical analysis for hatching rate showed that control were significantly different $(P<0.05)$ when compared with all treatments but not significant different among treatments $(P>0.05)$.

During 30 days of nurshing, it was seen that reared fries boths control and treatment groups had a good survival rate more than $85.33 \pm 3.06 \%$. However, statistical analysis showed that there is no significant effect $(P>0.05)$ of heat shocks treatments on the survival rate (Table 2). This result is better when compared with previous experiments where many larvae failed to survive or dead prior to first feeding (Pandian and Vardaraj, 1987; Haniffa et al., 2004), or only a few larvae $(0.2-16.9 \%)$ were survive (Hersberger and Hostuttler, 2005). According to Pandian and Koteeswaran (1998) the deaths of larvae due to physical shocks that occur in the early stages of rearing activity are caused by several factors: mosaic chromosomes, aneuploid, cell shrinkage, high cytological process failure and homozigosity.

Table 2. Hatching rate and survival rate of stripped catfish ( $P$. hypophthalmus) during 30 days rearing period at various treatments and control.

\begin{tabular}{ccc}
\hline Initial shock treatment & \multicolumn{2}{c}{ Parameters } \\
\cline { 2 - 3 } (min after fertilization) & Hatching Rate $(\%)$ & Survival Rate $(\%)$ \\
\hline 28.0 & $8.07 \pm 1.42^{\mathrm{b}}$ & $96.00 \pm 4.36$ \\
28.5 & $4.12 \pm 3.87^{\mathrm{b}}$ & $98.67 \pm 1.53$ \\
29.0 & $8.93 \pm 1.60^{\mathrm{b}}$ & $90.33 \pm 6.66$ \\
29.5 & $7.13 \pm 3.28^{\mathrm{b}}$ & $91.67 \pm 10.12$ \\
30.0 & $6.80 \pm 1.98^{\mathrm{b}}$ & $93.33 \pm 3.51$ \\
30.5 & $5.35 \pm 0.80^{\mathrm{b}}$ & $91.67 \pm 4.16$ \\
Control & $86.09 \pm 7.62^{\mathrm{a}}$ & $85.33 \pm 3.06$ \\
\hline
\end{tabular}

Values given under different superscripts are significantly different $(\mathrm{P}<0.05$ level).

\section{Abnormality}

Table 3 shows that larvae abnormalities were found in all heat shock treatments but it was not found in control. The heat shock of 42 ${ }^{0} \mathrm{C}$ for 2.5 minutes at innitial time of 30.5 and 30 minutes after fertilization were the treatments that tend caused the higher abnormality i.e. $20.96 \%$ and $27.60 \%$. While the other heat shock treatments were caused lower abnormality ranged between $12.36 \%-15.51$ $\%$, however in control was not found any abnormal larvae. Nevertheless, the statistical test showed no significant effect $(P>0.05)$ on abnormality. Higher abnormalities were observed by Mukti (2005) on carp (Cyprinus carpio Linn) treated with heat shock before the first mitosis resulted in an abnormality of 24.86 $\pm 8,37 \%$. 
Table 3. Larvae abnormality of stripped catfish ( $P$. hypophthalmus) caused by heat shock treatments

\begin{tabular}{lccccccc}
\hline \multirow{2}{*}{$\begin{array}{l}\text { Re- } \\
\text { plicates }\end{array}$} & $28^{\prime}$ & $28.5^{\prime}$ & $29^{\prime}$ & $29.5^{\prime}$ & $30^{\prime}$ & $30.5^{\prime}$ & Control \\
\cline { 2 - 8 } & 15.47 & 7.69 & 10.22 & 10.34 & 38.75 & 11.86 & 0.00 \\
2 & 13.79 & 0.00 & 17.55 & 5.96 & 32.40 & 13.93 & 0.00 \\
3 & 8.20 & 30.99 & 18.77 & 20.77 & 11.64 & 37.10 & 0.00 \\
\hline
\end{tabular}

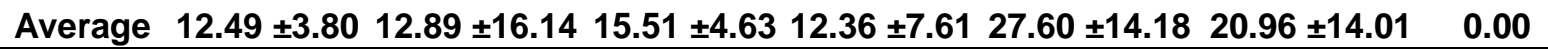

Observations on abnormal larvae that most of dead occured post hatching and only a few can survived until the end of the experiment as shown in Figure 1. Characteristic of abnormal larvae that was found in this experiment were varied such as spinal bent (Figure 1), curved tail and unproportional body shape. According to Haniffa et al. (2004) and Varadaraj and Pandian (1989) some eggs that hatched after being given a heat shock treatment show morphological abnormalities such as short and curved tails, egg yolk deformities, spinal deformities and head shape abnormalities. Furthermore, Carman (1992) states that the heat shock given in the early phases of embryonic development can cause damage on embryonic membrane so that it can produce abnormal individuals.

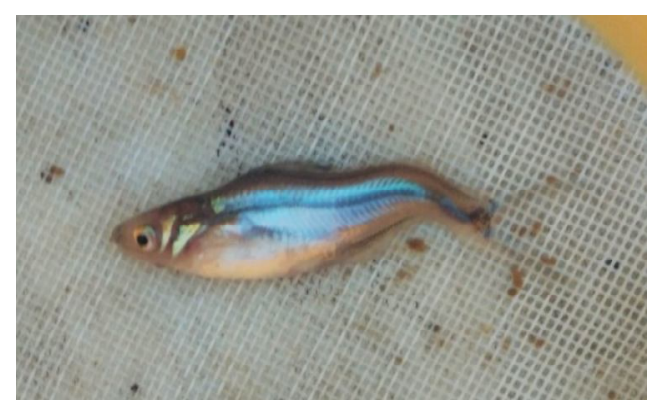

Figure 1. Typical abnormality in stripped catfish (P. hypophthalmus)

Specific growth rate (SGR)

Observation on both body length and body weight showed that SGR of treatment groups tend higher than control. Lenght SGR and weight SGR in treatment groups were 5.60
$\%-6.56 \%$ and $15.82 \%-18.62 \%$ respectively. While in control were $4,58 \%$ and $13,70 \%$ (Table 4). Nevertless, statistical analysis indicated that heat shock treatments had no significant effect on both lenght and weight specific growth rate $(P>0.05)$.

Table 4. Specific growth rate of stripped catfish ( $P$. hypophthalmus) during nurshing period

\begin{tabular}{lcc}
\hline \multirow{2}{*}{ Treatment } & \multicolumn{2}{c}{ Parameter } \\
\cline { 2 - 3 } & Lenght SGR (\%) & Weight SGR (\%) \\
\hline $28^{\prime}$ & $5.60 \pm 3.65$ & $15.82 \pm 12.54$ \\
$28.5^{\prime}$ & $6.56 \pm 5.08$ & $18.62 \pm 17.13$ \\
$29^{\prime}$ & $5.84 \pm 3.51$ & $16.96 \pm 15.06$ \\
$29.5^{\prime}$ & $6.14 \pm 4.73$ & $17.49 \pm 15.75$ \\
$30^{\prime}$ & $5.85 \pm 3.92$ & $17.43 \pm 15.55$ \\
$30.5^{\prime}$ & $6.34 \pm 5.41$ & $17.01 \pm 15.05$ \\
Control & $4.58 \pm 2.44$ & $13.70 \pm 6.77$ \\
\hline
\end{tabular}


Different results were reported by Don and Avtalion, (1988) in blue tilapia that applied physical shock treatment caused growth retardation. Similarly, Sparrow (1979) in Kadi (2007) that organisms from mechanical shocks before the first mitotic cause growth delays compared with no shock. Not only in fish, in some plants according to Sleper et al., (2006)

\section{Feed conversion ratio}

Calculation of feed conversion ratio based on 10 days sequencial sampling are presented in Table 5. The data show that feed conversion ratio values in heat shock treatment groups varied between $1.17-1.26$ and control of 1.47. However, there is no significant differences between treatment groups and control $(P>0.05)$. This result is no different from that obtained by Handayani et al. (2014) in explains that this no-different growth phenomenon caused by shock only increases the size of the merismatic cells, but the total number of cells does not increase. However, in common carp (C. carpio Linn) according to Mukti et al. (2005) that heat shock applied before the first mitosis can increase the fish growth.

djambal fish fed with commercial, giving the best feed conversion value of 1.15. Moreover, higher feed conversion results were obtained by Da et al. (2016) using various compositions of feed and commercial feed as a benchmark for striped catfish ranging from $1.42 \pm 0.2$ to 2.10 \pm 0.1 . When compared with the results of previous research, the value of feed conversion in control and heat shock treatments is still quite good and in the normal range for the growth of striped catfish.

Table 5. Feed conversion ratio (FCR) of stripped catfish ( $P$. hypophthalmus) during nurshing period

\begin{tabular}{|c|c|c|c|c|c|c|c|}
\hline \multirow{2}{*}{ Sampling } & \multicolumn{7}{|c|}{ FCR } \\
\hline & $28^{\prime}$ & $28.5^{\prime}$ & $29^{\prime}$ & $29.5^{\prime}$ & $30^{\prime}$ & $30.5^{\prime}$ & control \\
\hline S1 & 1.17 & 1.09 & 1.24 & 1.20 & 1.19 & 1.24 & 1.69 \\
\hline S2 & 1.46 & 1.53 & 1.33 & 1.43 & 1.55 & 1.54 & 1.24 \\
\hline S3 & 1.16 & 0.90 & 1.15 & 1.11 & 1.04 & 0.94 & 1.48 \\
\hline Average & $1.26 \pm 0.17$ & $1.17 \pm 0.32$ & $1.24 \pm 0.09$ & $1.25 \pm 0.17$ & $1.26 \pm 0.26$ & $1.24 \pm 0.30$ & $1.47 \pm 0.22$ \\
\hline
\end{tabular}

This results indicated that physically heat shock treatments did not affect on feed efficiency. This phenomenon is same as the statement of Chourrout et al. (1986) and Cui et al. (2013) that heat shock that applied before first mitosis tends to lead to poor growth both in fish and shellfish (Dunham 2004). According to Nordrum et al. (2000) both growth performance and FCR of aquatic organisms are strongly influenced by the performance of the intestines in utilizing the substances of feed source including the presence of anti-nutrients in the feed that was given. Furthermore, $\mathrm{Da}$ et al. (2016) adds that the presence of low amino acids in feed also has a significant effect on growth performance and FCR. However, there are many other factors such as age, species, maintenance quality of water as media and genetic aspect that also affect the FCR performance.

\section{Conclusions}

There is no evidence that heat shock treatment before the first mitosis affects specific growth rate and feed conversion ratio but has a major impact on zygote survival and abnormalities in hatched stripped catfish larvae.

\section{Acknowledgements}

North Branch Office of West Java Maritime Affairs and Fisheries and Ministry of Risearch, Technology and Higher Education of the Republic of Indonesia that supported this research.

\section{References}

Akter, M., Islam, M.J., Mian, S., Shikha, F.H., Rahman, M.H., Kamal, M., 2014. Changes in fillet quality of pangas catfish (Pangasianodon hypophthalmus) during frozen storage. World Journal of Fish and Marine Sciences 6,146-155.

Buulolo, A., 2016. Tetraploidization of Stripped Catfish Pangasianodon hypophthalmus using Heat Shock. Thesis Pascasarjana, IPB Bogor. 37 pp. 
Carman, O., 1992. Chromosome Set Manipulation in Some Warm-Water Fish. Doctoral Thesis, Tokyo University of Fisheries, Tokyo. $131 \mathrm{pp}$.

Chourrout, D., Chevassus, B., Krieg, F., Happe, A., Burger, G., Renard, P., 1986. Production of second generation triploid and tetraploid rainbow trout by mating tetraploid males and diploid females potential of tetraploid fish. Theoretical and Applied Genetics 72, 193-206.

Cui, L., Fang, L.B., Yu, Y.Y., Wang, W.M., Zhou, X.Y., Abbas, K., 2013. Reciprocal hybrids among diploid, tetraploid dojo loach, Misgurnus anguillicaudatus, and large-scale loach, Paramisgurnus dabryanus: fertilization, survival and growth performance. Journal of the World Aquaculture Society 44, 415-424.

Da, C.T., Lundh, T., Lindberg, J.E., Berg, H., 2016. Growth performance, feed utilization and biological indices of Tra catfish (Pangasianodon hypophthalmus) cultured in net cages in pond fed diets based on locally available feed resources. International Aquatic Research 8, 309-321.

De Silva, S.S., Anderson, T.A., 1995. Fish nutrition in aquaculture. Springer Press, London. 319 pp.

Ding, J., Chang, Y., Wang, Z., Song, J., 2007 Polyploidy induction by hydrostatic pressure shock and embryo development of sea cucumber, Apostichopus japonicus. Chinese Journal of Oceanology and Limnology 25, 184-190.

Don, J., Avtalion R.R., 1988. Production of viable tetraploid tilapias using the cold shock technique. Bamidgeh 40, 17-21.

Dunham RA. 2004. Aquaculture and fisheries biotechnology: genetic approaches. Cambridge, Mass.: CABI Publishing. 372 pp.

Effendie, M.I., 2002. Fisheries Biology. Yayasan Dewi Sri, Bogor. 109 pp.

Fetherman, E.R., Lepak, J.M., Harris, D.J., 2015. Optimizing triploid walleye production in Colorado. Colorado Parks and Wildlife. 1-8 pp.

Gil, H.W., Kong, H.J., An, C.M., Kim, B.S., Lim, S.G., Park, I.S., 2016 Cytogenetic study of diploid and induced tetraploid in Korean rose bitterling, Rhodeus uyekii. Springer Plus 5, 186.
Handayani, I., Nofyan, E., Wijayanti, M., 2014. Optimal Feeding Rate for Growth and Survival Rate of Pangasius djambal Fingerlings. Jurnal Akuakultur Rawa Indonesia 2, 175-187.

Haniffa, M.A., Sridhar, S., Nagarajan, M., 2004. Induction of triploidy and tetraploidy in stinging catfish, Heteropneustes fossilis (Bloch), using heat shock. Aquaculture Research 35, 937-942.

Hershberger, W.K., Hostuttler, M.A., 2005. Variation in time to first cleavage in rainbow trout Oncorhynchus mykiss embryos: a major factor in induction of tetraploids. Journal of the World Aquaculture Society 36, 96-102.

Ibrahim, Y., Soelistyowati, D., Carman, O., 2017. Triploidy of striped catfish Pangasianodon hypophthalmus: growth performance and gonadal development. Jurnal Akuakultur Indonesia 16, 76-82.

Islami, S.N., Reza, M.S., Mansur, M.A., Hossain, M.I., Shikha, F.H., Kamal, M., 2014. Rigor index, fillet yield and proximate composition of cultured striped catfish (Pangasianodon hypophthalmus) for its suitability in processing industries in Bangladesh. Journal of Fisheries. 2, 157-162.

Kadi, A., 2007. Manipulation of polyploidy to obtain a new superior strain. Oseana 32 , 1-11.

KKP., 2017. Annual report. Directorate General of Aquaculture. $40 \mathrm{pp}$.

Lagler, K.F., Bardach, J.E., Miller, R.R., Passino, D.R.M., 1977. Ichthyology. John Willey and Sons Inc., New York-London. $506 \mathrm{pp}$.

Lebeda, I., Flajshans, M., 2015. Technical note: production of tetraploid sturgeons. Journal of Animal Science 93, 37593764.

Lefevre, F., Mireille, C., Bugeon, J., Laurent, L., Medale, F., Quillet, E., 2015. Selection for muscle fat content and triploidy affect flesh quality in pan-size rainbow trout, 
Oncorhynchus mykiss. Aquaculture 448, 569-577.

Mukti, A.T., Rustidja., Sumitro, S.B., Djati, M.S., 2005. Poliploidization of carp (Cyprinus carpio L.). Biosain 1, 22-36.

Mukti, A.T., 2005. The difference in success rates of carp polyploidization (Cyprinus carpio Linn.) through heat shock. Berkala Penelitian Hayati 10, 133-138.

Myers, J.M., Hershberger, W.K., 1991. Early growth and survival of heat-shocked and tetraploid-derived triploid rainbow trout (Oncorhynchus mykiss). Aquaculture 96, 97-107.

Nordrum, S., Bakke-McKellep, A.M., Krogdahl, A., Buddington, R.K., 2000. Effects of soybean meal and salinity on intestinal transport of nutrients in Atlantic salmon (Salmo salar L.) and rainbow trout (Oncorhynchus mykiss). Comp. Biochem. Physiol part B 125, 317-335.

Pandian, T.J., Varadaraj, K., 1987. Techniques to produce $100 \%$ male tilapia. AGA. The ICLARM Quarterly 13, 3-5.

Pandian, T.J., Koteeswaran, R., 1998. Ploidy induction and sex control in fish. Hydrobiology 384, 167-243.

Sleper, D., Allen, Poehlman, J.M., 2006. Breeding Field Crops. Blackwell Publisher. IOWA. 424 pp.

Tave, D., 1993 Genetics for fish hatchery managers. Second edition, Van Nostrand Reinhold, New York, 267-304 pp.

Thorgaard, G.H., 1983. Chromosome set manipulation and sex control in fish. Fish Physiology 9, 405-434.

Varadaraj, K., Pandian, T.J., 1989. Induction of allotriploids in the hybrids of Oreochromis mossambicus female $X$ red tilapia male. Proceedings: Animal Sciences 98, 351358.

Zhan, S.H., Glick, L., Tsigenopoulos, C.S., Otto, S.P., Mayrose, I., 2014. Comparative analysis reveals that polyploidy does not decelerate diversification in fish. Journal of Evolutionary Biology 27, 391-403. 